\title{
PERANAN PROGRAM KEAGAMAAN TERHADAP PEMULIHAN KONSEP KENDIRI BANDUAN WANITA DI MALAYSIA
}

THE ROLE OF RELIGIOUS PROGRAM TO RECOVERY SELF CONCEPT OF WOMEN OFFENDERS IN MALAYSIA

\section{Siti Jamiaah Abdul Jalil', Yusmini Md Yusoff**, Rozmi Ismail ${ }^{* * *}$}

${ }^{* *}$ Akademi Pengajian Islam. Universiti Malaya. 50603.

Kuala Lumpur. Malaysia.

${ }^{* * *}$ Fakulti Sains Sosial dan Kemanusiaan. Universiti

Kebangsaan Malaysia. 43600. Bangi. Malaysia.

Emel: *sitijamiaah82@gmail.com

\begin{abstract}
Khulasah
Berdasarkan statistik Jabatan Penjara Malaysia (JPM), populasi banduan wanita semakin meningkat dari tahun ke tahun (tahun 2011; 8,230 orang, tahun 2012; 8,774 orang, tahun 2013; 11,221 orang). Beberapa kajian menunjukkan kecenderungan melakukan perbuatan menyimpang berkait dengan faktor keadaan konsep kendiri individu. Justeru, pihak JPM telah merangka modul pemulihan kepada banduan yang mana antara modul utama dilaksanakan ialah modul keagamaan. Rentetan itu, kajian ini dilakukan bagi mengenal pasti keadaan semasa konsep kendiri banduan wanita dan mengenal pasti peranan program keagamaan terhadap pemulihan konsep kendiri mereka. Soal selidik Skala Asas Nilai Agama Devian (SANAD) digunakan bagi mengetahui tahap nilai keagamaan responden dan Six Factor Self Concept Scale (SFSCS) pula digunakan bagi mengetahui keadaan konsep kendiri mereka. Seramai 141 orang banduan wanita warganegara terlibat dalam kajian ini. Hasil kajian menunjukkan program pemulihan melalui pendekatan keagamaan mampu mempengaruhi pembentukan konsep kendiri banduan wanita. Kefahaman agama yang tinggi,
\end{abstract}


kekuatan akidah dan pelaksanaan ibadah dan syariat dapat membantu pembinaan konsep kendiri banduan wanita yang lebih positif.

Kata kunci: Program agama, pemulihan, konsep kendiri, banduan wanita, Islam.

\begin{abstract}
According to the statistics of Malaysian Prisons Department (MPD), women offender population is increasing from year to year (in 2011; 8,230 people, in $2012 ; 8,774$ people, in 2013; 11,221 people). Some studies showed, the tendency to take action deviating is associated with an individual self-concept. In the meantime, the MPD has developed a recovery module to prisoners. Among the major modules implemented are modules religious. Consequently, the study was conducted to identify the current state of the self-concept of women offenders and identify the role of religious programs on the recovery of their self-concept. Basic Scale Questionnaire Religious Values Devian (BRVSD) was used to determine the extent of respondents religiosity and Six Factor Self Concept Scale (SFSCS) was used to determine the state of their self-concept. A total of 141 women offenders involved in the study. The results showed a recovery program through religious approach be able to influence self-concept of women offenders. Accordingly, high religious understandingand strength of faith as well as great implementation of worship and shari ah can develop more positive selfconcept of women offenders.
\end{abstract}

Keywords: Religious programme, rehabilitation, self-concept, women offender, Islam.

\title{
Pendahuluan
}

Beberapa kajian telah menunjukkan terdapat perkaitan di antara konsep kendiri dan tingkah laku devian atau tingkah laku menyimpang. Misalnya, kajian yang dilakukan oleh Rosenberg et al. mendapati faktor keyakinan diri mempunyai hubungan yang kuat dengan 
tingkah laku delinkuen. ${ }^{1}$ Delinkuen merujuk kepada sikap melanggar undang-undang atau melakukan perkara yang tidak diterima masyarakat. ${ }^{2}$

Melalui dapatan Gold dan Mann menunjukkan kebanyakan remaja delinkuen secara signifikan memiliki keyakinan diri yang rendah. ${ }^{3}$ Begitu juga kajian yang dilakukan oleh McMurran et al. melaporkan bahawa banduan wanita mendapat skor keyakinan diri yang rendah berbanding banduan lelaki. ${ }^{4}$ Walaupun banyak kajian memberi tumpuan terhadap aspek keyakinan diri, namun menurut Fitts dan Warren, konsep kendiri dan keyakinan diri mempunyai perkaitan yang sama antara satu sama lain. $^{5}$

Jelas di sini konsep kendiri negatif merupakan salah satu faktor yang menyebabkan seseorang itu bertingkah laku devian. Seseorang yang memiliki konsep kendiri negatif cenderung untuk bertingkah laku devian. Sebaliknya mereka yang mempunyai konsep kendiri positif kurang berisiko untuk bertingkah laku devian. ${ }^{6}$ Ini menunjukkan pembinaan konsep kendiri adalah penting dalam proses pemulihan golongan devian. Sebagaimana kajian yang dilakukan oleh Hermann et al. terhadap kumpulan berisiko, menunjukkan berlaku perubahan yang

${ }^{1}$ Rosenberg, F. R., Rosenberg. M. \& McCord. J., "Self-Esteem and Delinquency," Journal of Youth and Adolescence 7(3) (1978): 279294.

${ }^{2}$ Kamus Dewan, ed. ke-4 (Kuala Lumpur: Dewan Bahasa \& Pustaka, 2005), 330, entri “delinkuen".

3 Gold, M., \& Mann, D.W., "Delinquency as a Defense," American Journal of Orthopschitry 42 (1972): 463-479.

4 McMurran et al., "Measuring Motivation to Change in Offenders", Psychology, Crime and Law 4 (1998): 43-50.

${ }^{5}$ Fitts, W.H. \& Warren, W.L., Tennessee Self-Concept Scale (TSCS:2), Manual $2^{\mathrm{th}}$ ed. (Los Angeles CA: Western Psychological Services, 1996), 26.

${ }^{6}$ Bernburg, J. G., "Labeling Theory," dalam Handbook on Crime and Deviance, ed. Krohn, M. D., Lizotte, A. J. \& Hall, G. P. (London: Springer, 2009), 187-204. 
lebih baik apabila mereka memiliki keyakinan diri yang lebih positif. ${ }^{7}$

Namun begitu, tidak semestinya konsep kendiri yang negatif memberi kesan yang negatif untuk diri. Ini kerana menurut Trice dan Roman konsep kendiri yang negatif juga boleh memberi kesan yang positif terutama dalam proses pencegahan dan pemulihan. ${ }^{8}$ Ini kerana, hanya individu yang sedar bahawa dirinya memiliki kekurangan atau keburukan sahaja yang berpotensi membaiki dan membangunkan dirinya berbanding mereka yang tidak sedar akan keburukan atau kelemahan diri. Ini juga selari dengan perspektif Islam yang menggalakkan setiap manusia untuk selalu melakukan muhasabah diri bagi mencari kesempurnaan dan kekurangan yang telah dilakukan. ${ }^{9}$ Melalui muhasabah diri manusia mampu untuk memperbaiki agar tidak bersarang di dalam hatinya sifatsifat tercela. ${ }^{10}$

\section{Pembinaan Konsep Kendiri dari Perspektif Islam}

Menurut Shavelon dan Bolus, konsep kendiri ialah tanggapan $^{11}$ atau penilaian ${ }^{12}$ individu terhadap dirinya yang meliputi kepercayaan, perasaan, sikap harga diri dan

7 Hermann, D.S, McWhirter, J.J., \& Sipsas-Hermann, A., "The Relationship Between Dimensional Self Concept and Juvenile Gang Involvement: Implications For Prevention, Intervantion, and Court Referred Diversion Programs," Behavioral Sciences and the Law 15 (1997): 181-194.

8 Trice, \& Roman, P., "Delabeling, Relabeling, and Alcoholics Anonymous," Social Problems 17 (1970): 538-546.

9 Damanhuri, Akhlak; Perspektif Pemikiran Tasawuf Abdurrauf AsSingkili (Banda Aceh: ArRijal Publisher, 2011), 214.

${ }^{10}$ Hanafi Mohamed, Penyakit Rohani dan Rawatannya dalam Islam (Kuala Lumpur: Pustaka Haji Abdul Majid, 1998), 133.

${ }^{11}$ Shavelson, R.J. \& Bolus, R., "Self-concept: The Interplay of Theory and Method," Journal Of Educational Psychology 74 (1982): 3-17.

12 Azizi Yahaya, Fawziah Yahya, Zurihanmi Zakaria \& Noordin Yahaya, Pembangunan Kendiri (Johor: UTM, 2005), 2. 
juga nilai. ${ }^{13}$ Bagi Habibah dan Noran pula konsep kendiri meliputi persepsi individu tentang diri dan alam sekelilingnya melalui derianya dan juga perasaan tentang kebolehannya yang meliputi keyakinan dan harga dirinya. ${ }^{14}$

Penjelasan teori pembentukan konsep kendiri turut dikemukakan oleh Rogers yang menunjukkan pembentukan konsep kendiri individu dipengaruhi oleh pandangan individu itu sendiri dan individu lain di sekelilingnya. ${ }^{15}$ Rajah 1 di bawah merupakan ringkasan teori tersebut.

Rajah 1: Pembentukan Konsep Kendiri Rogers

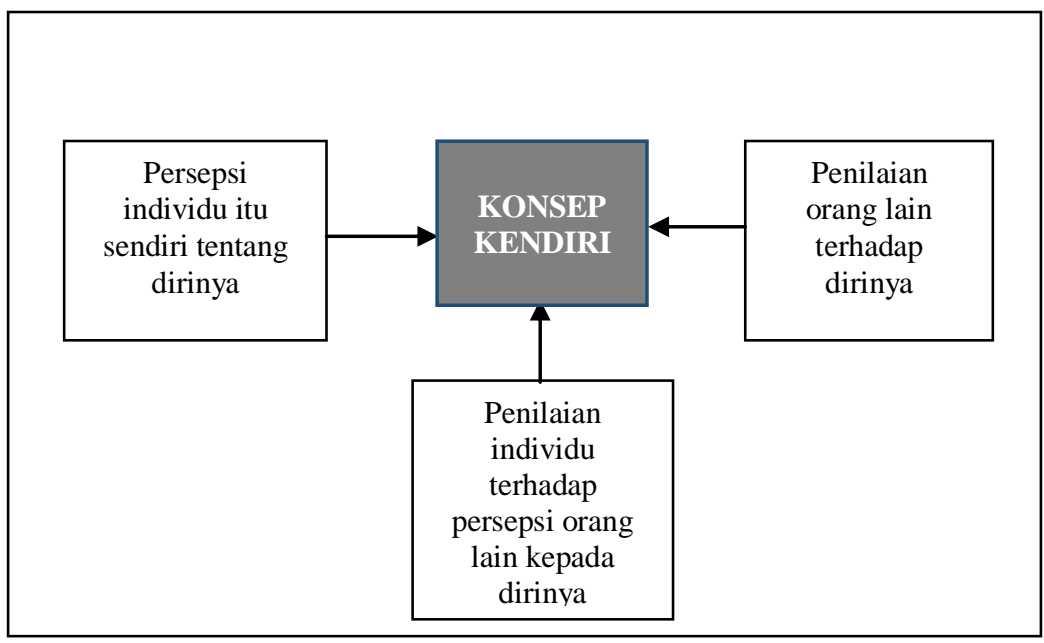

Sumber: Azizi Yahaya et. al, Pembangunan Kendiri, 3.

Berasaskan definisi tersebut, terdapat perbezaan perbincangan berkaitan pembangunan konsep kendiri dari

${ }^{13}$ Mohd Salleh Lebar, Asas Psikologi Perkembangan (Kuala Lumpur: Utusan Publication \& Distributors Sdn. Bhd, 1994), 185.

14 Habibah Elias \& Noran Fauziah Yaakub, Psikologi Personaliti (Kuala Lumpur: Dewan Bahasa dan Pustaka, 2006), 98.

15 Rogers, C. R., Client-centered Therapy: Its Current Practice, Implications, and Theory (New York:Houghton Mifflin, 1951), 498. 
sudut pandangan Islam dan Barat. Perbezaan ini tidak dapat dielakkan memandangkan tunjang perbincangan terhadap matlamat kehidupan manusia itu sendiri berbeza di antara Barat dan Islam. Tunjang matlamat kehidupan manusia dalam Islam berkait rapat dengan alam ketuhanan dan alam ghaib seperti persediaan menuju hari pengadilan atau hari Akhirat. ${ }^{16}$

Oleh itu, setiap pemikiran dan tindakan mengambil kira kesannya terhadap hubungan dengan Allah SWT dan balasan di hari Akhirat nanti. Berbeza dengan Barat, perkara-perkara yang berkait dengan tuhan dan alam ghaib hanyalah sebagai konsep pemikiran manusia sahaja. ${ }^{17}$ Jadi tidak hairanlah, bagi mereka pemikiran dan tindakan manusia lebih dipengaruhi oleh penilaian dan pandangan orang lain di sekelilingnya.

Dari perspektif Islam, individu bukan hanya dipengaruhi oleh elemen penilaian terhadap pandangan manusia sahaja, malah turut dipengaruhi oleh elemen penilaian terhadap pandangan Pencipta iaitu Allah SWT. Islam telah menyediakan garis panduan kepada manusia sebagai kayu ukur untuk pembinaan konsep kendiri iaitu dengan mengambil kira pandangan Allah SWT terhadap diri melalui tuntutan dan larangan yang termaktub di dalam al-Quran dan hadis. Apabila seseorang manusia itu menilai dirinya berdasarkan pandangan Allah SWT, maka ia akan berusaha melakukan segala tuntutan Allah SWT demi mencapai keredaan-Nya.

Secara ringkasnya, Rajah 2 di bawah menunjukkan elemen yang membentuk konsep kendiri menurut perspektif Islam:

16 Yusuf al-Qaradawi, Iman dan Kehidupan, (terj.) Fachruddin HS (Shah Alam: Dewan Pustaka Fajar, 2005), 29-45.

17 Mostafa Kamal Mokhtar, "Konsep Pembangunan Rohani Manusia: Kajian Perbandingan di antara Sufisme dan Psikologi," Jurnal Psikologi Malaysia 15 (2001): 1-20. 
Rajah 2: Pembentukan Konsep Kendiri menurut Perspektif Islam

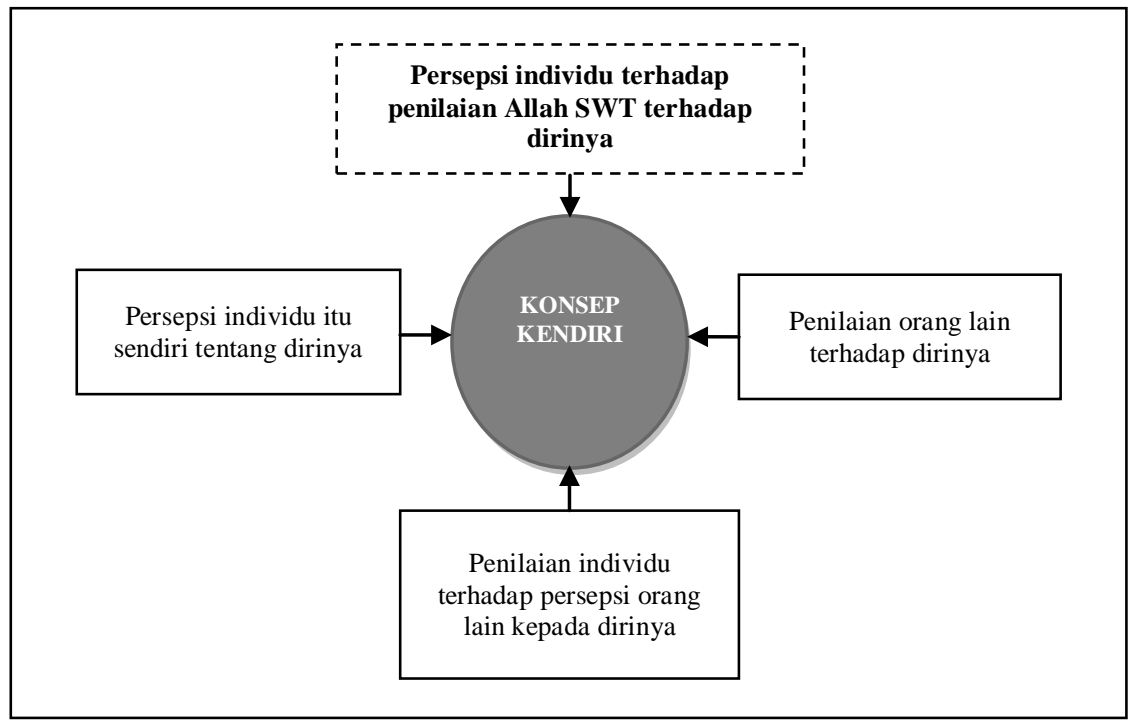

Selain dari itu, satu pandangan yang berbeza terhadap pembinaan konsep kendiri positif di dalam Islam berbanding Barat. Ini kerana Islam berpandangan konsep kendiri perlu kepada keseimbangan. Apa yang dimaksudkan dengan keseimbangan ialah penilaian atau persepsi individu terhadap dirinya tidak terlalu rendah sehingga melahirkan sifat putus asa dan juga tidak terlalu tinggi sehingga melahirkan sifat ujub ${ }^{18}$.

Ini dinyatakan oleh Ibn Mas 'ūd bahawa kebinasaan itu terletak dalam dua perkara iaitu putus asa dan ujub. Menurut beliau kebahagiaan tidak boleh diperoleh dengan sifat malas. Orang berputus asa itu biasanya tidak lagi suka berusaha dan tidak pula mencari apa-apa yang dicita-

${ }^{18}$ Sifat ujub bermaksud berasa bangga pada diri sendiri, berasa hairan terhadap diri sendiri dengan sebab adanya sesuatu dan lain-lain perkara. Abū Hạamid al-Ghazālī, Ihyȳ' 'Ulūm al-Dìn, taḥqīq As'ad alȘāgharji, jil. 4 (Damsyiq: Dār al-Fayhā', 2010), 584-585. 
citakannya. Manakala, sifat ujub pula menyebabkan seseorang itu menganggap tiada gunanya untuk berusaha kerana seolah-olah individu berkeyakinan dirinya sudah mencapai kebahagiaan, keselamatan dan kesejahteraan. ${ }^{19}$

Oleh itu, dengan mengutamakan pandangan Allah SWT dalam penilaian diri dapat menyeimbangkan konsep kendiri individu agar tidak terlalu negatif dan tidak terlalu positif. Ini kerana Allah SWT bukan sahaja tidak menyukai manusia yang lemah seperti memiliki konsep kendiri negatif sehingga melahirkan sikap putus asa. ${ }^{20}$ Malah, Allah SWT juga tidak menyukai manusia yang mengagumi diri iaitu bersifat ujub yang boleh menjadikan manusia itu bersikap sombong dan bongkak. ${ }^{21}$ Sifat ini jugalah pendorong manusia untuk melakukan kemungkaran dan perkara di luar batasan norma.

\section{Terapi Keagamaan dalam Pemulihan Konsep Kendiri}

Menurut perspektif Islam, matlamat pembinaan konsep kendiri individu ialah bagi memperoleh keseimbangan sebagaimana yang diperjelaskan sebelum ini. Keseimbangan yang dipengaruhi dengan sifat mahmudah seperti tawaduk (rendah hati), tawakal, sabar, dan lain-lain serta terhindar dari sifat mazmumah khususnya sifat putus asa dan ujub. Keseimbangan konsep kendiri ini terhasil berdasarkan kekuatan hubungan dengan Allah SWT.

Kekuatan hubungan ini hanya boleh diperoleh melalui keadaan jiwa yang sihat kesan daripada gabungan hati, akal, nafsu dan roh yang berfungsi mengikut landasan yang sebenar sebagaimana yang disarankan oleh al-Quran dan hadis Nabi SAW. Menurut Ibn Qayyim, roh atau jiwa yang berada di dalam keadaan yang baik dan sihat menjadikan seseorang itu dapat melihat kebenaran

${ }^{19}$ Ibn Mas `ūd, dalam al-Ghazālī, Ihyā' 'Ulūm al-Dīn, 4:585.

20 Al-Quran, Surah Hūd 11:9-11; Surah Yūsuf 12:87; Surah al-Isrā’ 17:83; Surah al-Rūm 30:36; Surah al-Fușṣilāt (41):49.

21 Al-Quran, Surah al-Tawbah (9):25; Surah al-Kahf (18):104; Surah al-Najm (53): 32; Surah al-Hashr (59): 2. 
dan keburukan sesuatu itu dengan jelas. ${ }^{22}$ Melalui jiwa yang sihat juga dapat membina sifat mahmudah dalam diri yang mendorong individu untuk melakukan kebaikan dan takut untuk melakukan kejahatan. ${ }^{23}$

Oleh itu, bagi memulihkan kembali konsep kendiri, seseorang individu perlu melakukan al-tawbah serta tazkiyah al-nafs. ${ }^{24}$ Sebagaimana termaktub dalam firman Allah SWT iaitu: ${ }^{25}$

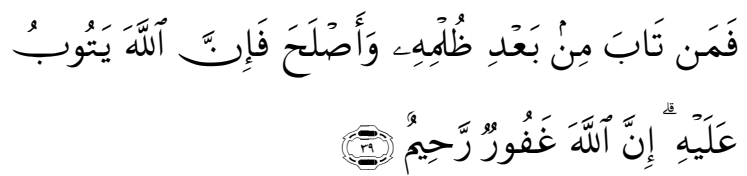

Terjemahan: Maka barang siapa yang bertaubat sesudah melakukan kejahatan itu, dan memperbaiki diri, maka sesungguhnya Allah menerima taubatnya. Sesungguhnya Allah Maha Pengampun lagi Maha Penyayang.

Seseorang hanya mampu melakukan taubat apabila timbul penyesalan dalam dirinya. Penyesalan itu lahir apabila seseorang itu menyedari kesilapan, kelemahan dan keburukan diri yang semua itu merupakan konsep kendiri negatif. Pada proses penyesalan, konsep kendiri negatif amat diperlukan. Trice dan Roman berpendapat konsep kendiri yang negatif boleh memberi kesan yang positif terutama dalam proses pemulihan. ${ }^{26}$ Ini kerana, hanya individu yang sedar bahawa dirinya memiliki kekurangan atau keburukan sahaja yang berpotensi membaiki dan

${ }^{22}$ Ibn Qayyīm al-Jawziyyah, Tuhfah al-Mawdūd bi Aḥkām al-Mawlūd, tahqiq 'Abd al-Qādir al-Arna'ūṭ (Damsyiq: Maktabah Dār al-Bayān, 1971), 300-302.

23 Mohammad Salleh, Terapi Solat Tahajud (Kuala Lumpur: PTS Millennia Sdn.Bhd. 2008), 72.

${ }^{24}$ Ṣāliḥ Aḥmad al-Shāmī, al-Muhadhdhab min Ihyā' Ulūm al-Dīn, jil. 2 (Damsyiq: Dār al-Qalam, 2010), 248-254.

${ }^{25}$ Surah al-Mā'idah 5:39.

${ }^{26}$ Trice \& Roman, Social Problems, 538-546. 
membangunkan dirinya berbanding mereka yang tidak sedar akan keburukan atau kelemahan diri. Namun, tidak berhenti di tahap penyesalan, dalam menuju taubat perlu kepada lahirnya nilai keinsafan yang membawa kepada usaha untuk membaiki kesilapan.

Menurut al-Ghazāli, taubat merupakan peluang kepada individu untuk membersihkan diri dari segala dosa yang telah dilakukan. ${ }^{27}$ Sesungguhnya Allah SWT akan menerima taubat sesiapa sahaja yang bertaubat dan mengharapkan pengampunan daripada-Nya. Sebagaimana yang dinyatakan dalam hadis Nabi SAW:

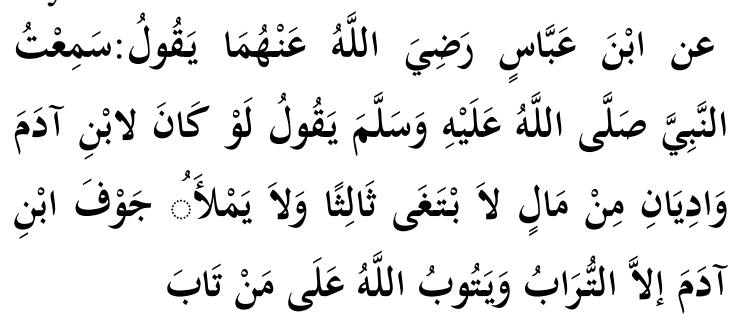

Terjemhan: Ibn 'Abbas r.a berkata, saya mendengar Nabi SAW bersabda: "Sekiranya anak Adam memiliki harta sebanyak dua bukit, nescaya ia akan mengharapkan untuk mendapatkan bukit yang ketiga, dan tidaklah perut anak Adam itu dipenuhi melainkan dengan tanah, dan Allah menerima taubat siapa sahaja yang bertaubat." ${ }^{28}$

Demikian itu, taubat perlu dilakukan dengan ikhlas dan bersungguh-sungguh iaitu tawbat nașūha $\bar{a}^{29}$ untuk kembali kepada perintah Allah SWT dengan menyesali di atas perbuatan dosa yang dilakukan dan memasang azam

${ }^{27}$ Al-Shāmī, al-Muhadhdhab min Ihyā' Ulūm al-Dīn, 2:248.

${ }^{28}$ Al-Bukhārī, Șaḥihh al-Bukhārī, ed. Muḥammad `Abd al-Qādir Aḥmad 'Ațā', jil. 3 (Kaherah: Dār al-Taqwā li al-Turāth, 2001), 314 , Hadis no. 5956, Bab no. 10, Kitab no. 61. Terjemahan dari aplikasi Ensiklopedi Hadits Kitab 9 Imam.

${ }^{29}$ Al-Quran, Surah al-Tahrīm (66):8. 
untuk menjauhkan diri daripada melakukan dosa serta tidak mengulanginya serta menyelesaikan apa-apa perkara yang berkaitan dengan kesalahan yang telah dilakukan seperti meminta maaf dan memulangkan kembali sesuatu pada tempatnya. ${ }^{30}$ Bagi Ibn Taymiyyah, taubat merupakan awal daripada tahap penyucian diri. ${ }^{31}$ Namun dalam pelaksanaan taubat, ia perlu seiring dengan pelaksanaan penyucian diri (tazkīyyah al-Nafs). ${ }^{32}$

Tazkiyah al-nafs merupakan satu proses penyucian jiwa daripada kekejian dan kekotoran yang berpunca daripada akhlak yang tercela. ${ }^{33}$ Melalui tazkiyyah al-nafs, ia dapat mengembalikan roh atau jiwa kepada fitrah sebenar. Fitrah yang merangkumi kesucian, kebaikan, dan selamat berdasarkan ketauhidan terhadap Allah SWT yang tersedia sejak lahir lagi. ${ }^{34}$ Menurut Basri Ibrahim et al., asas penting tazkiyyah al-nafs berdasarkan al-Quran, Sunnah dan amalan salaf al-ṣālih ialah keikhlasan hati dengan mengukuhkan tauhid dan akidah melalui pegangan teguh kepada al-Quran dan Sunnah, serta beriman dengan qada' dan qadar dan juga hari akhirat, di samping bertawakal kepada Allah SWT. ${ }^{35}$

Menurut al-Ghazāli, dalam melaksanakan tazkiyyah al-nafs terdapat dua proses yang perlu dilalui oleh setiap

\footnotetext{
${ }^{30}$ Al-Ghazālī, al-Muhadhdhab min Ihyā' Ulūm al-Dīn,, 2:249.

${ }^{31}$ Kholil Lur Rochman, "Terapi Penyakit Hati Menurut Ibn Taimiyah Dalam Perspektif Bimbingan Konseling Islam”, Jurnal Dakwah dan Komunikasi: Komunika 3(2) (Julai- Dis 2009): 196-221.

${ }^{32}$ Al-Quran, Surah al-Nisā' 4:17; Surah al-Baqarah 2:222.

33 Fariza Md.Sham, Salasiah Hanin Hamjah \& Mohd. Jurairi Sharifudin, Personaliti dari Perspektif al-Ghazali (Bangi: Universiti Kebangsaan Malaysia, UKM, 2008), 44.

34 H. Imam Malik, Psikologi Umum Sebuah Pengantar (Surabaya: Lembaga Kajian Agama dan Filsafat (eLKAF), 2005), 246-248.

35 Basri Ibrahim, Mohd Safri Al-Azhari \& Ahmad Tarmizi Taha, Pembersihan Jiwa menurut al-Quran, al-Sunnah \& Amalan Salafus Soleh (Batu Caves: Al-Hidayah House of Publishers Sdn. Bhd, 2013), 401-455.
} 
individu iaitu mujāhadah al-nafs (al-takhallī) dan riyādah al-nafs (al-tahalli). ${ }^{36}$

Rajah 3: Bentuk Pelaksanaan Tazkīyyah al-Nafs

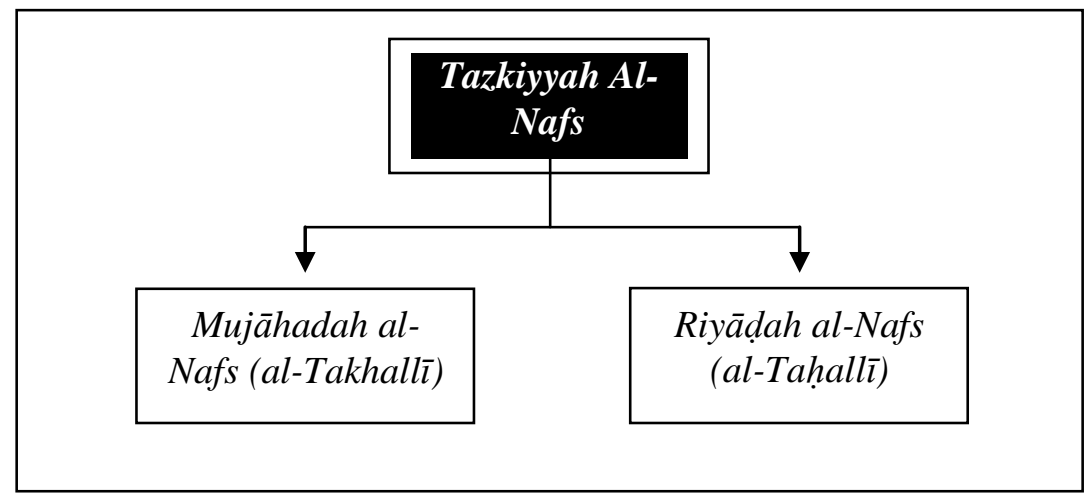

Mujāhadah al-nafs merupakan usaha yang bersungguh-sungguh untuk membersihkan jiwa daripada sifat-sifat tercela atau mazmumah. Ia merupakan satu kaedah untuk menentang dan mengawal nafsu syahwat dan menghapuskan sifat-sifat tercela atau mazmumah yang terdapat dalam diri seperti hasad, dengki, marah, cinta dunia, takbur, riyak dan lain-lain lagi. Riyādah alnafs adalah usaha melatih diri menanam dan menghiasi jiwa dengan amalan mulia.

Riyādah al-nafs perlu dilakukan secara beransuransur dan berperingkat-peringkat. Bermula dengan amalan- mulia yang mudah atau kecil sehingga peringkat yang susah atau besar. Sehinggakan amalan mulia yang susah itu menjadi senang kerana sudah menjadi kebiasaan. Melalui amalan ini akan membentuk jiwa dengan sifat mahmudah seperti sabar, syukur, tawakal, takwa, reda dan lain-lain lagi, sekali gus membentuk jiwa yang kuat dan membina peribadi dan akhlak yang mulia. ${ }^{37}$

\footnotetext{
${ }^{36}$ Al-Ghazālī, Ihyyā' 'Ulūm al-Dīn, 3:611.

${ }^{37}$ Al-Ghazālī, Ihyyà' 'Ulūm al-Dīn, 3:595.
} 
Berdasarkan kaedah yang dikemukakan oleh tokoh ilmuwan Islam, terdapat tiga kaedah utama yang dikenal pasti menjadi asas tazkiyyah al-nafs. Pertama adalah melakukan solat. $^{38}$ Solat merupakan saluran yang menghubungkan manusia secara terus dengan Allah SWT. Ini kerana ibadah solat merangkumi aspek zikrullah ${ }^{39}$ seperti zikir, tasbih, takbir, tahmid dan doa yang menjadi metode komunikasi antara hamba dengan Penciptanya. ${ }^{40}$ Antara kesan positif yang mampu terbina dalam membentuk konsep kendiri yang seimbang melalui ibadah solat ialah membina nilai kebergantungan dengan Allah SWT kesan daripada rasa lemahnya diri sebagai hambaNya.

Selain daripada itu, ibadah solat mampu membina nilai pengharapan terhadap pertolongan Allah SWT melalui doa yang disampaikan. Nilai kebergantungan dan pengharapan mampu menghindarkan sifat mazmumah yang berkait dengan pembinaan konsep kendiri iaitu sifat ujub dan putus asa. Semakin banyak seseorang itu melakukan amalan solat (melengkapkan solat wajib dan ditambah dengan solat sunat), maka semakin kerap seseorang itu berhubung dengan Penciptanya. Sekali gus, menguatkan lagi hubungan roh dengan alam ketuhanan.

Namun begitu, kesan solat seseorang itu adalah berbeza berdasarkan keikhlasan dan kesungguhan mereka. Penguasaan dan penghayatan sepenuh hati ketika melakukan amalan solat dapat memberi impak yang mendalam dalam diri pelakunya. Sebaliknya, tanpa

38 Al-Ghazāli, "Khulāșah al-Tașānif fīi al-Tașawwuf," dalam Majmū ‘ah Rasā'il al-Imām al-Ghazālì (Beirut: Dār al-Minhajil, 1994), 108.

39 Che Zarrina Sa'ari, "Penyait Gelisah (Anxiety / al-Halū') dalam Masyarakat Islam dan Penyelesaiannya menurut Psiko-Spiritual Islam," Jurnal Usuluddin 14 (2001): 1-22.

40 Ahmad Hisham Azizan \& Che Zarrina, "Terapi Solat dalam Menangani Penyakit Gelisah (Anxiety) menurut Perspektif Psikoterapi Islam,” Jurnal Usuluddin 10 (2009), 1-43. 
kehadiran hati dan kurangnya tumpuan terhadap amalan tersebut, maka kesannya adalah hambar. ${ }^{41}$

Kedua adalah berpuasa. Puasa dapat mengawal diri daripada melakukan kejahatan. Berpuasa dapat memberi kecerdasan kepada fikiran dan melemahkan nafsu syahwat. Menurut Haron Din, puasa dapat melemahkan nafsu yang kuat kerana orang yang kenyang akan bertambah dan kuat nafsu syahwatnya. ${ }^{42}$

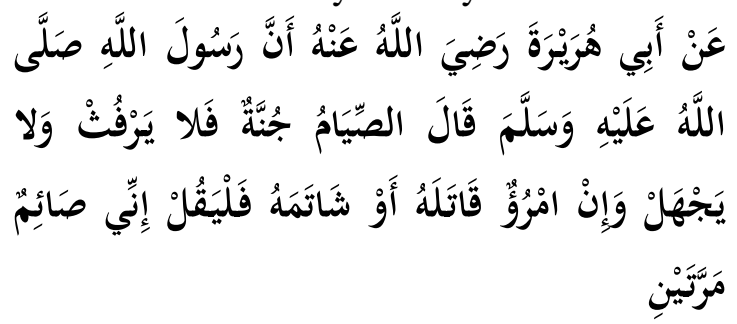

Maksud: Dari Abū Hurayrah r.a., bahawa Rasulullah SAW bersabda, "Puasa itu merupakan benteng. Maka (orang yang melaksanakannya) janganlah berbuat kotor dan jangan pula bertindak bodoh. Apabila ada orang yang mengajaknya berkelahi atau menghinanya maka katakanlah aku sedang berpuasa (mengulang ucapannya dua kali)."43

Hadis di atas menunjukkan bahawa, dalam puasa terkandung latihan untuk mengendalikan motivasi dan emosi, serta memperkuatkan kehendak untuk mengalahkan dorongan nafsu syahwat. Latihan kesabaran

${ }^{41}$ Mohd Radhi Ibrahim, Akidah dan Pembangunan Tamadun (Bandar Baru Nilai: Kolej Universiti Islam Malaysia, 2006), 66-69.

42 Haron Din, Islam: Ibadah Pembina Tamadun Manusia (Kuala Lumpur: PTS Millennia, 2007), 70.

43 Al-Bukhārī, Șaḥ̄h Bukhārī, 1:453-454, Hadis no. 1761, Bab no. 2, Kitab no. 15. Terjemahan merujuk dari aplikasi Ensiklopedi Hadits Kitab 9 Imam. 
yang terdapat dalam ibadah puasa dalam menahan lapar dan haus juga membentuk nilai murni. ${ }^{44}$

Ketiga adalah membaca al-Quran. Al-Quran adalah penawar dan rahmat kepada manusia. ${ }^{45}$ Oleh kerana itu, umat Islam sangat digalakkan agar membaca al-Quran kerana ia mampu membentuk dalaman diri ke arah yang lebih positif. Melaluinya bukan sahaja mampu menjadi penawar bagi penyakit-penyakit batin malah sebagai petunjuk kebenaran untuk mencapai kesejahteraan. ${ }^{46}$

Al-Ghazāli menjelaskan peranan ibadah merupakan penggerak ke arah pembentukan peribadi yang baik. ${ }^{47} \mathrm{Di}$ samping amalan ibadah seperti solat, puasa, membaca alQuran, zakat dan haji, ibadah juga meliputi pelbagai aspek yang berkait dengan makna kepatuhan dengan segala perintah Allah SWT dan menjauhi serta meninggalkan larangannya. ${ }^{48}$

\section{Terapi Agama dalam Modul Pemulihan Banduan Wanita Jabatan Penjara Malaysia (JPM)}

Di Malaysia, Jabatan Penjara Malaysia (JPM) bukan sahaja sebagai sebuah institusi bertanggungjawab melaksanakan hukuman ke atas banduan yang telah disabitkan kesalahan, malah menjadi institusi yang berusaha merangka dan melaksanakan pemulihan kepada banduan. Selain daripada aspek disiplin, psikologi, kemahiran, dan sosial, aspek kerohanian juga antara salah satu aspek pemulihan yang diberi keutamaan oleh pihak JPM.

Ini dapat dilihat di dalam Pelan Pembangunan Insan (PPI) yang merupakan kerangka modul pemulihan

\footnotetext{
${ }^{44}$ Muhammad 'Uthmān Najātī, al-Hadīth al-Nabawī wa 'Ilm al-Nafs (Kaherah: Dār al-Shurūq, 1988), 320.

45 Al-Quran, Surah al-Isrā' 17:82.

${ }^{46}$ Al-Quran, Surah Yūnus 10:57.

47 Fariza, Salasiah \& Mohd. Jurairi, Personaliti dari Perspektif alGhazali, 73.

48 Al-Ghazālï, "Khulāṣah al-Tașānif fī al-Tașawwuf," 108.
} 
banduan yang juga dikenali sebagai penghuni. Modul PPI yang dibina berasaskan sistem fasa menjadikan proses pemulihan penghuni lebih tersusun dan sistematik. Terdapat 4 fasa dibentuk dalam modul ini iaitu:

i. Fasa 1: Program Pembinaan Disiplin/Orientasi (2 bulan)

ii. Fasa 2: Program Pembangunan Sahsiah (6 bulan)

iii. Fasa 3: Program latihan dan Kemahiran Sosial (tiada had masa)

iv. Fasa 4: Pra-bebas (banduan yang mempunyai baki hukuman tidak melebihi 1 tahun dan memenuhi syarat-syarat yang telah ditentukan).

Modul PPI Fasa 2 yang dikenali sebagai Program Pembangunan Sahsiah merupakan program yang menekankan pendekatan keagamaan. Oleh itu, banduan wanita di Fasa 2 lebih banyak mengikuti aktiviti agama berbanding fasa-fasa yang lain. ${ }^{49}$ Terdapat tiga modul $1^{50}$ yang dilaksanakan di dalam Fasa 2 ini dan salah satunya ialah modul keagamaan yang dikenali sebagai Modul Halaqah.

Dalam fasa ini, banduan wanita dibimbing untuk mendalami ilmu agama dan melaksanakan ibadah secara berkumpulan (berjemaah). Ia bertujuan untuk membina jati diri dan membentuk sikap positif penghuni di samping melahirkan penghuni yang insaf dan bertaubat. ${ }^{51}$ Fasa ini merupakan core treatment dalam PPI yang dilaksanakan selama enam bulan yang memberi penekanan kepada aspek pembentukan jati diri dan perubahan tingkah laku.

${ }^{49}$ Cik Dazilawati Bt. Daud (Kader JAKIM) dalam temu bual dengan penulis, 6 Jun 2011 di Penjara Wanita Kajang.

50 Fasa 2 merupakan Program Pembangunan Sahsiah yang mengandungi tiga modul iaitu (1) Modul Terapi Komuniti (Therapeutic Community) atau dikenali sebagai TC, (2) Modul Halaqah, dan (3) Modul Kaunseling.

${ }^{51}$ LaporanTahunan Jabatan Penjara Malaysia 2005, 57. 
Penghuni akan mengikuti program yang bersesuaian mengikut kriteria yang telah ditetapkan. ${ }^{52}$

Modul Halaqah yang menekankan aspek pengukuhan sahsiah merupakan modul pemulihan alternatif untuk memulihkan penghuni yang beragama Islam yang tidak terlibat dengan pengaruh dadah. ${ }^{53}$ Ia dilaksanakan selama enam bulan dan berkonsepkan sistem pondok. Program ini bertujuan melahirkan penghuni yang dapat menghayati dan melaksanakan ajaran agama Islam sebagai cara hidup. Modul ini memberi penekanan kepada pengajian dan pengamalan ajaran Islam dalam kehidupan seharian. Penghuni yang mengikuti program ini akan didedahkan dengan cara hidup Islam yang sebenar dengan menerapkan nilai-nilai murni agar membantu mereka menjadi seorang Muslim yang bertakwa.

Program ini berasaskan empat objektif utama pelaksanaannya iaitu; (1) untuk memberi ilmu pengetahuan agama Islam kepada penghuni berkenaan khususnya fardu ain, (2) supaya penghuni dapat mempraktikkan ajaran Islam yang sebenar, (3) melahirkan penghuni yang mempunyai jati diri Muslim, dan (4) membantu jabatan dalam program pemulihan penghuni lain. Semua ini adalah bagi mencapai visinya iaitu untuk melahirkan peserta yang mempunyai daya ketahanan diri yang mantap, menginsafi dan tidak akan mengulangi kesilapan silam berlandaskan syariat Islam serta berguna kepada agama, bangsa dan tanah air. Selain dari itu,

52 Banduan wanita yang bebas dari pengaruh dadah akan mengikuti Modul Halaqah. Manakala, banduan wanita yang masih berada di bawah pengaruh dadah akan mengikuti Modul Terapi Komuniti Puan Zuriani Bt Mamat (Pembantu Guru Agama (PGA) di Penjara Wanita Kajang) dalam temu bual dengan penulis, pada 6 Jun 2011.

53 Mereka yang berada di dalam pengaruh dadah lebih didedahkan dengan Modul Terapi Komuniti (Therapeutic Community), namun turut didedahkan dengan Modul Halaqah. 
program ini juga bertindak sebagai kelas pengajian kepada saudara baru yang memeluk Islam. ${ }^{54}$

Antara teras pengisian agama yang disediakan melalui Modul Halaqah ialah melalui kelas pengajian alQuran, fikah, tauhid, sirah dan akhlak (Rujuk ringkasan dalam Rajah 4). ${ }^{55}$

Rajah 4: Ringkasan Modul Halaqah JPM

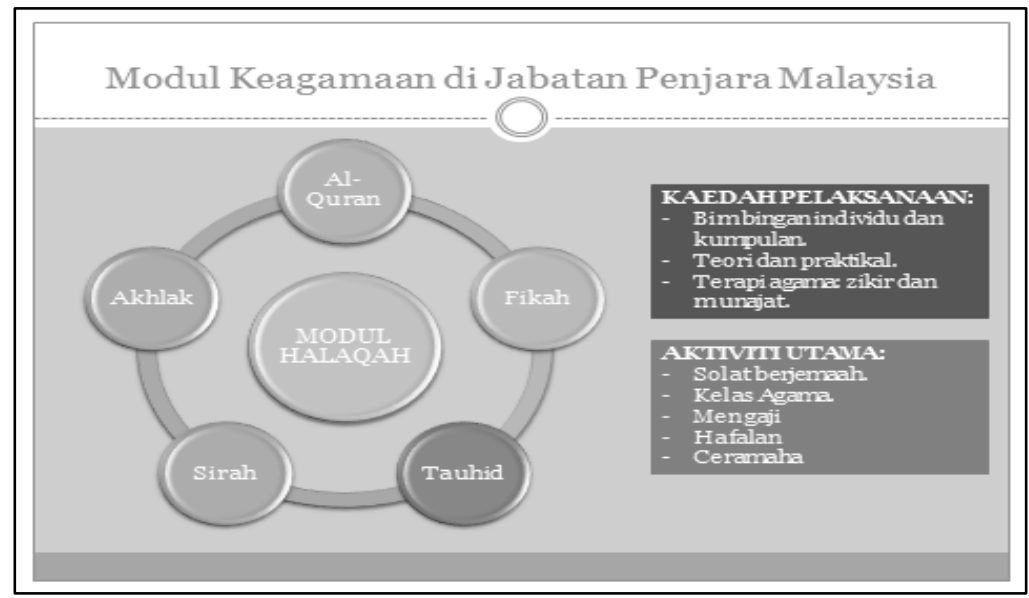

Kelas pengajian Islam yang diadakan adalah mengikut kurikulum pendidikan Islam yang dikeluarkan oleh JPM dengan usaha sama Jabatan Kemajuan Islam Malaysia (JAKIM). Kelas pengajian ini diadakan pada setiap hari dan biasanya diadakan di surau penghuni. Tenaga pengajar adalah terdiri daripada Penolong Hal Ehwal Islam, Pembantu Hal Ehwal Islam, Pembantu Guru Agama dan guru agama luar dari Jabatan Agama Islam negeri dan lain-lain organisasi pertubuhan Islam.

\footnotetext{
${ }^{54}$ Program Halaqah: Di Institusi Penjara, Dokumentasi Jabatan Penjara Malaysia, tidak diterbitkan, 3.

55 Garis Panduan Kurikulum Pengajian dan Bimbingan Islam serta Aktiviti Harian Halaqah Institusi Penjara Malaysia, Unit Agama Bahagian Pemulihan dan Rawatan Jabatan Penjara Malaysia, tidak diterbitkan, 1-24.
} 
Beberapa program keagamaan yang lain seperti pengimarahan masjid/surau, sambutan perayaan/hari kebesaran Islam, Program Ihya' Ramadhan, Majlis Ibadah Korban/Aqiqah, Idil Adha, Majlis Perujian Tilawah AlQuran, hafazan Al-Quran, pertandingan marhaban dan pertandingan nasyid peringkat penghuni JPM, Forum Hal Ehwal Islam, Program Tafaqquh Fiddin, bengkel ibadah serta kursus dan ceramah motivasi. ${ }^{56}$

\section{Metode kajian}

Kajian ini menggunakan metode soal selidik yang telah diedarkan kepada 141 orang banduan wanita daripada 5 buah penjara di Malaysia. Soal selidik Skala Asas Nilai Agama Devian (SANAD) digunakan bagi mengetahui tahap nilai keagamaan responden dan soal selidik Six Factor Self Concept Scale (SFSCS) telah digunakan bagi mengukur konsep kendiri semasa responden kajian ini. Soal selidik SANAD mengandungi 30 soalan yang berkait dengan nilai asas keagamaan yang berkaitan pemahaman dan penghayatan terhadap akidah, ibadah/syariat dan akhlak. Manakala soal selidik SFSCS merangkumi 36 item yang mewakili 6 konsep berkaitan kendiri iaitu kemampuan disukai, nilai moral, penyelesaian tugasan, kelemahan mudah terganggu, kuasa dan bakat.

Responden kajian telah dibahagikan mengikut tiga kumpulan berdasarkan fasa pemulihan iaitu Fasa 1 bagi kumpulan yang belum mengikuti Program Pembangunan Sahsiah (PPS) iaitu modul pemulihan keagamaan, Fasa 2 bagi kumpulan yang sedang mengikuti PPS, dan Fasa 3 iaitu kumpulan yang telah mengikuti PPS. Data yang diperoleh dianalisis bagi menjawab dua hipotesis kajian yang dibina iaitu:

\footnotetext{
${ }^{56}$ Laporan Tahunan Jabatan Penjara Malaysia 2002, 13-15.
} 
Hipotesis 1: $\quad \mathrm{H}^{\mathrm{o}}$ : Tidak terdapat perbezaan yang signifikan konsep kendiri banduan wanita mengikut fasa pemulihan.

$\mathrm{H}^{1}$ : Terdapat perbezaan yang signifikan konsep kendiri banduan wanita mengikut fasa pemulihan.

Hipotesis 2: $\quad \mathrm{H}^{\mathrm{o}}$ : Tidak terdapat hubungan yang signifikan di antara nilai keagamaan dengan konsep kendiri banduan wanita.

$\mathrm{H}^{1}$ : Terdapat hubungan yang signifikan di antara nilai keagamaan dengan konsep kendiri banduan wanita.

\section{Dapatan kajian}

\section{a. Responden kajian}

Berdasarkan carta pai dalam Rajah 5 di bawah menunjukkan pecahan kumpulan responden mengikut fasa pemulihan dalam Pelan Pembangunan Insan (PPI). Seramai 75 orang yang mewakili 53.2 peratus daripada jumlah responden merupakan mereka yang berada di Fasa 1 iaitu kumpulan responden yang masih belum mengikuti modul keagamaan. Manakala, kumpulan responden yang sedang melalui modul keagamaan iaitu Fasa 2 pula ialah seramai 37 orang yang mewakili 26.2 peratus. Selebihnya, iaitu seramai 29 orang yang mewakili 20.6 peratus ialah mereka yang berada di Fasa 3 iaitu kumpulan responden yang telah mengikuti modul keagamaan. ${ }^{57}$

${ }^{57}$ Pecahan kumpulan fasa pemulihan ini selari dengan corak populasi banduan wanita warganegara iaitu jumlah banduan wanita di fasa satu jauh lebih besar berbanding fasa-fasa pemulihan berikutnya. Ini kerana kebanyakan mereka terlibat dengan kesalahan yang membawa kepada hukuman singkat (penjara di bawah tempoh 6 bulan). 
Siti Jamiaah, Yusmini \& Rozmi, "Peranan Program Keagamaan,” Afkār Vol. 18 Issue 2 (2016): 193-228

Rajah 5: Carta Pai Pecahan Responden mengikut Fasa Pemulihan

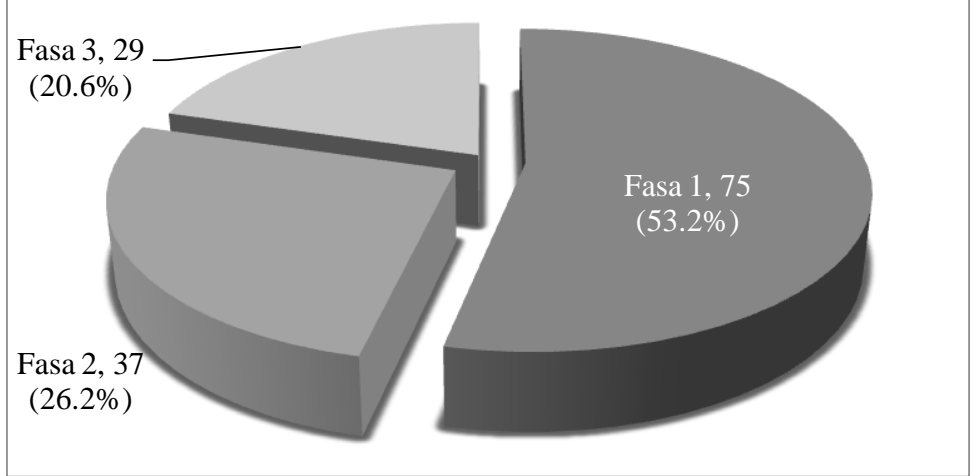

\section{i. Hipotesis 1}

$\mathrm{H}^{\mathrm{o}}$ : Tidak terdapat perbezaan yang signifikan konsep kendiri banduan wanita mengikut fasa pemulihan.

$\mathrm{H}^{\mathbf{1}}$ : Terdapat perbezaan yang signifikan konsep kendiri banduan wanita mengikut fasa pemulihan.

Keputusan ujian ANOVA sehala menunjukkan bahawa perbezaan konsep kendiri antara fasa pemulihan adalah signifikan $[\mathrm{F}(2,138)=3.51, \mathrm{p}<.05]$. Maka pengkaji menolak hipotesis nul $\left(\mathrm{H}^{\circ}\right)$ dan membuat keputusan bahawa secara keseluruhan terdapat perbezaan konsep kendiri antara fasa pemulihan.

Keputusan ujian Post Hoc melalui analisis Tukey HSD menunjukkan bahawa nilai min konsep kendiri bagi pasangan kumpulan Fasa 2 dan Fasa 3 (perbezaan min = 14.84, $\mathrm{p}<.05$ ) adalah signifikan. Ini bererti bahawa perbezaan secara keseluruhan di atas adalah disebabkan oleh perbezaan kumpulan pasangan Fasa 2 dan Fasa 3. Nilai min kumpulan Fasa 2 ( $\mathrm{M}=149.68, \mathrm{SD}=27.96, \mathrm{n}=37)$ menunjukkan bahawa konsep kendiri kumpulan responden 
dalam fasa tersebut lebih rendah daripada kumpulan di Fasa $3(M=164.52, \mathrm{SD}=19.54, \mathrm{n}=29)$.

Berdasarkan keputusan analisis di atas, pengkaji melaporkan bahawa banduan wanita yang telah mengikuti Program Pembangunan Sahsiah (PPS) (Fasa 3) memiliki konsep kendiri lebih positif berbanding dengan banduan wanita yang sedang mengikuti PPS (Fasa 2). Bentuk graf min plot dalam Rajah 6 di bawah jelas menunjukkan bahawa nilai min konsep kendiri bagi banduan wanita yang sedang mengikuti PPS jauh lebih rendah berbanding dengan kumpulan banduan wanita yang telah mengikuti PPS. Walau bagaimanapun, tidak ada perbezaan konsep kendiri yang signifikan antara banduan wanita (Fasa 1) yang belum mengikuti PPS ( $\mathrm{M}=156.28$, $\mathrm{SD}=20.69, \mathrm{n}=75$ ) dengan banduan wanita dalam dua fasa yang lain.

Rajah 6: Graf Plot Min Konsep Kendiri Banduan Wanita Mengikut Fasa Pemulihan

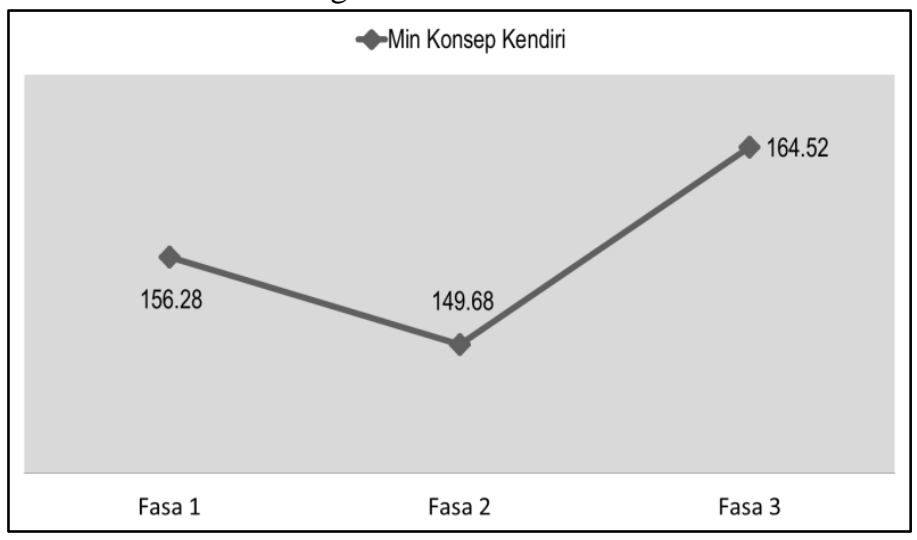

Berdasarkan graf plot dalam Rajah 6 di atas menunjukkan berlaku penurunan nilai min konsep kendiri banduan wanita yang belum mengikuti PPS (Fasa 1) kepada banduan wanita yang sedang mengikuti PPS (Fasa 2). Walaupun penurunannya tidak ketara tetapi ini menunjukkan bahawa Program Pembangunan Sahsiah 
(PPS) mampu membina nilai penyesalan dan keinsafan dalam diri banduan wanita. Nilai min konsep kendiri yang rendah menunjukkan keadaan subjek yang menyedari kelemahan dan keburukan diri mereka.

Seterusnya, graf plot menunjukkan peningkatan ketara dari Fasa 2 kepada Fasa 3. Ini menjelaskan bahawa banduan wanita yang telah mengikuti PPS (Fasa 3) memiliki konsep kendiri yang lebih positif daripada banduan wanita yang sedang mengikuti PPS (Fasa 2). Peningkatan secara ketara ini menunjukkan gabungan pengetahuan agama yang diperoleh melalui PPS dan ilmu kemahiran dalam pemulihan Fasa 3 dapat membantu membina nilai diri banduan wanita yang lebih positif.

Penilaian konsep kendiri dapat diperincikan lagi melalui enam sub skala yang diukur melalui SFSC iaitu (1) kemampuan disukai, ${ }^{58}$ (2) nilai moral, ${ }^{59}$ (3) penyelesaian tugasan, ${ }^{60}$ (4) tidak mudah terganggu, ${ }^{61}$ (5) kuasa ${ }^{62}$ dan (6) bakat $^{63}$. Berdasarkan keputusan ujian ANOVA dalam Jadual 1 di bawah, menunjukkan terdapat dua sub skala dalam konsep kendiri yang menunjukkan nilai perbezaan yang signifikan antara fasa pemulihan iaitu

58 Kriteria sub skala kemampuan disukai berkait dengan rasa menyenangkan dan gembira bila bersama dan ramah serta mesra.

59 Kriteria sub skala nilai moral berkait dengan rasa setia, patuh, bersifat benar, mempunyai kualiti dinilai sebagai mulia dan boleh dipercayai.

${ }^{60}$ Kriteria sub skala penyelesaian tugasan berkait dengan merasa diri sebagai pekerja yang rajin, produktif,mempunyai tabiat kerja yang baik dan keupayaan untuk mengurus dan menyelesaikan tugas-tugas dengan berkesan serta bagus dalam menepati had masa yang ditetapkan.

${ }^{61}$ Kriteria sub skala tidak mudah terganggu berkait dengan perasaan tidak mudah malu, berkeyakinan, dan tidak sukar melaksanakan sesuatu di bawah tekanan.

62 Kriteria sub skala kuasa berkait dengan rasa dominan, kuat, memiliki kekuatan dan ketabahan.

63 Kriteria sub skala bakat berkait dengan rasa bakat semula jadi, kreatif, memiliki keupayaan istimewa yang semula jadi (kebolehan semula jadi, bakat semula jadi). 
Siti Jamiaah, Yusmini \& Rozmi, "Peranan Program Keagamaan," Afkār Vol. 18 Issue 2 (2016): 193-228

bagi sub skala penyelesaian tugasan $[\mathrm{F}(2,138)=3.15$, $\mathrm{p}<.05]$ dan sub skala bakat $[\mathrm{F}(2,138)=5.31, \mathrm{p}<.05]$.

Jadual 1: Ringkasan ANOVA perbezaan sub skala konsep kendiri berdasarkan Fasa Pemulihan

\begin{tabular}{|c|c|c|c|c|c|}
\hline \multicolumn{6}{|c|}{ ANOVA } \\
\hline & & $\begin{array}{c}\text { Jumlah Kuasa } \\
\text { Dua }\end{array}$ & \multicolumn{2}{|r|}{$\begin{array}{l}\text { Min Kuasa } \\
\text { Dua }\end{array}$} & F \\
\hline \multirow[t]{3}{*}{ Kemampuan disukai } & Antara kumpulan & 62.862 & 2 & 31.431 & .887 \\
\hline & Dalam kumpulan & 4887.705 & 138 & 35.418 & \\
\hline & Jumlah & 4950.567 & 140 & & \\
\hline \multirow[t]{3}{*}{ Nilai moral } & Antara kumpulan & 123.506 & 2 & 61.658 & 2.111 \\
\hline & Dalam kumpulan & 4029.317 & 138 & 29.212 & \\
\hline & Jumlah & 4152.823 & 140 & & \\
\hline \multirow[t]{3}{*}{ Penyelesaian tugasan } & Antara kumpulan & 189.854 & 2 & 94.927 & $3.150^{*}$ \\
\hline & Dalam kumpulan & 4159.224 & 138 & 30.139 & \\
\hline & Jumlah & 4349.078 & 140 & & \\
\hline \multirow[t]{3}{*}{ Tidak mudah terganggu } & Antara kumpulan & 122.086 & 2 & 61.043 & 2.207 \\
\hline & Dalam kumpulan & 3817.205 & 138 & 27.661 & \\
\hline & Jumlah & 3939.291 & 140 & & \\
\hline \multirow[t]{3}{*}{ Kuasa } & Antara kumpulan & 49.533 & 2 & 23.293 & .687 \\
\hline & Dalam kumpulan & 4721.119 & 138 & 33.884 & \\
\hline & Jumlah & 4770.652 & 140 & & \\
\hline \multirow[t]{3}{*}{ Bakat } & Antara kumpulan & 452.906 & 2 & 225.263 & $5.305^{*}$ \\
\hline & Dalam kumpulan & 5856.895 & 138 & 42.461 & \\
\hline & Jumlah & 6309.801 & 140 & & \\
\hline
\end{tabular}

$* \mathrm{k}<0.05$

\section{Penyelesaian Tugasan}

Bagi mengetahui pasangan kumpulan fasa yang mempunyai perbezaan yang signifikan, ujian Post Hoc dijalankan melalui analisis Tukey HSD. Analisis menunjukkan bahawa nilai min sub skala penyelesaian tugasan hanya berbeza secara signifikan bagi pasangan kumpulan Fasa 2 dan Fasa 3 (perbezaan $\min =-3.32$, $\mathrm{p}<.05)$. Nilai min kumpulan Fasa $2(\mathrm{M}=28.54, \mathrm{SD}=6.42$, $\mathrm{n}=37$ ) yang lebih rendah menunjukkan bahawa konsep kendiri dari aspek penyelesaian tugasan bagi kumpulan responden dalam fasa tersebut lebih rendah daripada kumpulan di Fasa 3 ( $M=31.86, \mathrm{SD}=4.24, \mathrm{n}=29)$. 
Siti Jamiaah, Yusmini \& Rozmi, "Peranan Program Keagamaan,” Afkār Vol. 18 Issue 2 (2016): 193-228

Rajah 7: Graf Plot Min Bagi Sub Skala Penyelesaian Tugasan

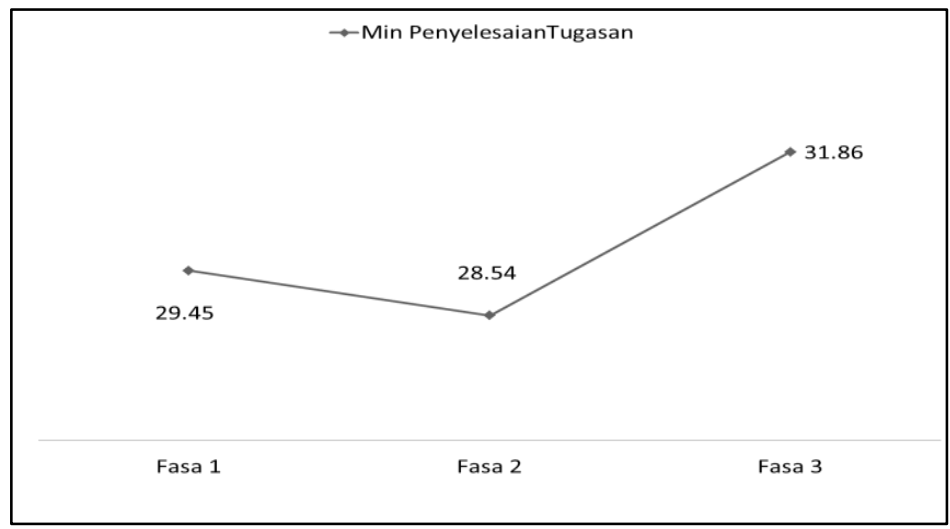

Graf plot min penyelesaian tugasan dalam Rajah 7 di atas memperlihatkan bahawa berlaku sedikit penurunan dari Fasa 1 kepada Fasa 2. Namun, kembali meningkat dengan ketara dari Fasa 2 kepada Fasa 3. Pengkaji mendapati gabungan pengetahuan agama dan ilmu kemahiran telah meningkatkan keyakinan dan kesungguhan banduan wanita dalam melaksanakan sesuatu tugasan. Ajaran Islam menuntut manusia menunaikan amanah dan tugasan diberikan dengan sebaiknya. Berlandaskan tuntutan agama dan tugas-tugas yang dilakukan di bengkel-bengkel kemahiran telah membuktikan kepada diri banduan wanita yang mereka mampu untuk melakukan tugas dengan baik. Secara tidak langsung membina konsep kendiri yang lebih positif.

\section{Bakat}

Bagi sub skala bakat pula, ujian Post Hoc menunjukkan bahawa wujud perbezaan signifikan bagi pasangan kumpulan Fasa 1 dengan Fasa 2 (perbezaan min $=3.42$, $\mathrm{p}<.05)$ dan pasangan kumpulan Fasa 2 dengan Fasa 3 (perbezaan $\min =-4.93, \mathrm{p}<.05$ ). Bagi pasangan kumpulan Fasa 1 dengan Fasa 2, nilai min kumpulan Fasa 1 $(\mathrm{M}=25.67, \mathrm{SD}=6.76, \mathrm{n}=75)$ menunjukkan bahawa konsep kendiri dari aspek bakat bagi kumpulan responden dalam 
fasa tersebut lebih tinggi daripada kumpulan di Fasa 2 $(\mathrm{M}=22.24, \mathrm{SD}=6.99, \mathrm{n}=37)$. Bagi pasangan kumpulan Fasa 2 dengan Fasa 3 juga menunjukkan bahawa nilai min kumpulan Fasa $3(\mathrm{M}=27.17, \mathrm{SD}=5.06, \mathrm{n}=29)$ lebih rendah daripada kumpulan di Fasa 2. Walau bagaimanapun, tidak terdapat perbezaan signifikan bagi pasangan kumpulan Fasa 1 dengan Fasa 3.

Berdasarkan graf plot bagi sub skala bakat dalam Rajah 8 di bawah menunjukkan berlakunya penurunan nilai min bakat dari Fasa 1 ke Fasa 2 dan naik kembali di Fasa 3. Pengkaji mendapati, pada peringkat awal banduan wanita memasuki penjara (Fasa 1), mereka berkeyakinan dengan bakat mereka sedia ada. Walaupun terdapat bakatbakat yang mereka miliki merupakan bakat yang mendorong mereka melakukan perbuatan di luar norma. Namun, melalui bimbingan, ceramah, dan tazkirah yang diperoleh dalam PPS dalam Fasa 2 telah memberi kesedaran mengenai perkara yang benar dan salah yang menyebabkan menurunnya tanggapan terhadap nilai bakat yang mereka miliki. Namun, melalui Program Kemahiran di Fasa 3 telah memberi peluang kepada subjek untuk kembali mengasah bakat mereka, sekali gus meningkatkan keyakinan semula terhadap bakat sebenar yang mereka miliki.

Rajah 8: Graf Plot Min Bagi Sub Skala Bakat

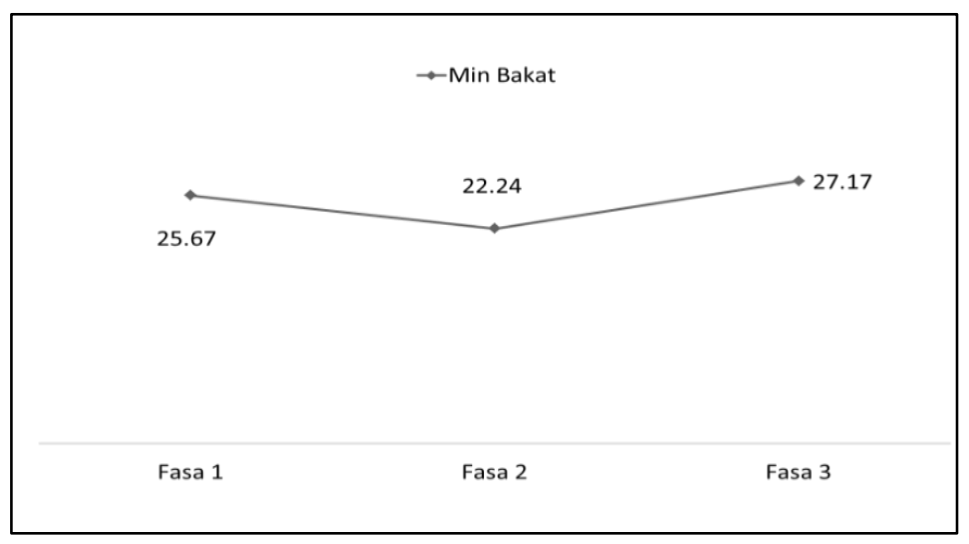


Kesimpulannya, pengkaji mendapati Program Pembangunan Sahsiah (PPS) dapat menimbulkan rasa kesedaran dan keinsafan dalam diri banduan wanita. Rasa keinsafan ini membantu membangunkan kembali diri mereka ke arah yang lebih positif disokong dengan peluang melalui pembinaan kemahiran diri semasa berada di Fasa 3. Nilai positif ini wujud terutama terhadap penilaian mereka dalam melaksanakan tugas yang diamanahkan dan kelebihan bakat yang mereka miliki.

\section{ii. Hipotesis 2}

$\mathrm{H}^{\mathrm{o}}$ : Tidak terdapat hubungan yang signifikan di antara nilai keagamaan dengan konsep kendiri banduan wanita.

$\mathrm{H}^{1}$ : Terdapat hubungan yang signifikan di antara nilai keagamaan dengan konsep kendiri banduan wanita.

Merujuk kepada Jadual 2 di bawah, keputusan ujian Korelasi Spearman menunjukkan bahawa terdapat hubungan positif di antara nilai keagamaan dengan konsep kendiri $(\mathrm{r}=.183, \mathrm{p}<0.05)$. Maka pengkaji menolak hipotesis nul $\left(\mathrm{H}^{\circ}\right)$ dan membuat keputusan bahawa terdapat hubungan yang signifikan antara nilai keagamaan dengan konsep kendiri banduan wanita. Keputusan analisis menunjukkan bahawa konsep kendiri banduan wanita semakin positif apabila nilai keagamaan semakin tinggi.

Jadual 2: Korelasi Spearman Rho Bagi Nilai Keagamaan,

Pemahaman Agama, Penghayatan Agama, Akidah, Syariat, Akhlak Dan Konsep Kendiri

\begin{tabular}{|c|c|c|c|c|c|c|c|}
\hline & & $\begin{array}{l}\text { NILAI } \\
\text { KAGAMAAN }\end{array}$ & Pemahaman & Penghayatan & Akidah & $\begin{array}{l}\text { Ibadah } \\
\text { Syariat }\end{array}$ & Alkhlak \\
\hline \multirow{3}{*}{ KONSEP KENDIRI } & Koefisien Korelasi & $.183^{*}$ & $.226^{* 8}$ & .119 & $.174^{8}$ & $.181^{8}$ & .106 \\
\hline & Sig. (2-tailed) & .030 & .007 & .161 & .040 & .032 & .211 \\
\hline & $\mathrm{N}$ & 141 & 141 & 141 & 141 & 141 & 141 \\
\hline
\end{tabular}


Jadual 2 di atas turut memperincikan korelasi di antara konsep kendiri dan sub skala dalam nilai keagamaan. Analisis menunjukkan terdapat hubungan positif di antara konsep kendiri dengan semua sub skala dalam nilai keagamaan responden (pemahaman, penghayatan, akidah, ibadah/syariat, dan akhlak). Daripada semua sub skala tersebut, tiga sub skala menunjukkan hubungan yang signifikan iaitu bagi sub skala pemahaman agama $(\mathrm{r}=.226, \mathrm{p}<0.01)$, sub skala akidah $(\mathrm{r}=.174, \mathrm{p}<0.05)$ dan sub skala ibadah/syariat $(\mathrm{r}=.181, \mathrm{p}<0.05)$.

Oleh itu, terdapat tiga aspek keagamaan yang mempunyai perkaitan dengan pembentukan konsep kendiri positif banduan wanita iaitu (1) peningkatan pemahaman terhadap pengetahuan agama, (2) pengukuhan akidah, dan (3) pelaksanaan ibadah/syariat. Ini menunjukkan banduan wanita memerlukan bimbingan agama untuk meningkatkan kefahaman mereka terutama terhadap perkara-perkara berkaitan akidah, dan ibadah/syariat dalam membantu membina konsep kendiri mereka yang lebih positif.

Jadual 3: Korelasi Spearman Rho Bagi Nilai Keagamaan dan Sub Skala Konsep Kendiri (Kemampuan Disukai, Nilai Moral, Penyelesaian Tugasan, Kelemahan Mudah Terganggu, Kuasa

Dan Bakat)

\begin{tabular}{|c|c|c|c|c|c|c|c|c|}
\hline \multicolumn{9}{|c|}{ KORELASI SPEARMAN'S RHO } \\
\hline & & $\begin{array}{l}\text { KONSEP } \\
\text { KENDIRI }\end{array}$ & $\begin{array}{l}\text { Kemampuan } \\
\text { disukai }\end{array}$ & $\begin{array}{l}\text { Nilai } \\
\text { moral }\end{array}$ & $\begin{array}{l}\text { Penyelesaian } \\
\text { tugasan }\end{array}$ & $\begin{array}{l}\text { Tidak } \\
\text { mudah } \\
\text { terganggu }\end{array}$ & Kuasa & Bakat \\
\hline \multirow{3}{*}{$\begin{array}{l}\text { NILAI } \\
\text { KEAGAMAAN }\end{array}$} & Koefisien Korelasi & $.183^{*}$ & .106 & $.268^{\prime \prime}$ & $.200^{\circ}$ & .056 & -.047 & .024 \\
\hline & Sig. (2-tailed) & .030 & .210 & .001 & .017 & .513 & .583 & .780 \\
\hline & $\mathrm{N}$ & 141 & 141 & 141 & 141 & 141 & 141 & 141 \\
\hline
\end{tabular}

Jadual 3 di atas pula menunjukkan korelasi nilai keagamaan dengan sub skala dalam konsep kendiri. Analisis mendapati nilai keagamaan mempunyai hubungan positif dengan semua sub skala dalam konsep 
kendiri kecuali sub skala kuasa. Namun, hanya dua sub skala konsep kendiri iaitu sub skala nilai moral $(\mathrm{r}=.268$, $\mathrm{p}<0.01)$ dan sub skala penyelesaian tugasan $(\mathrm{r}=.200$, $\mathrm{p}<0.05)$ mempunyai hubungan yang signifikan dengan nilai keagamaan. Ini menjelaskan bahawa semakin tinggi nilai keagamaan banduan wanita semakin positif penilaian mereka terhadap diri terutama terhadap nilai moral dan penyelesaian tugasan.

Oleh yang demikian, nilai keagamaan yang baik dapat membina nilai moral banduan wanita yang baik serta mendorong mereka melakukan tugasan dan tanggungjawab dengan lebih baik. Namun, sebaliknya bagi konsep kendiri dari aspek nilai kuasa yang menunjukkan hubungan yang negatif dengan nilai keagamaan. Walaupun tidak mempunyai hubungan yang signifikan, dapatan ini secara tidak langsung menunjukkan nilai keagamaan mengurangkan rasa berkuasa, dominan dan memiliki kekuatan dalam diri banduan wanita.

\section{Perbincangan}

Keputusan Hipotesis 1 menunjukkan program keagamaan mampu memberi kesedaran dengan menimbulkan penyesalan dan keinsafan dalam diri banduan wanita. Ini berdasarkan tahap konsep kendiri banduan wanita yang lebih rendah semasa sedang mengikuti Program Pembangunan Sahsiah (PPS) berbanding mereka yang belum dan telah mengikuti program tersebut. Menurut Ibn Qayyim, penyesalan merupakan salah satu ciri menuju kepada taubat. ${ }^{64}$

Oleh sebab itu, Trice dan Roman berpendapat konsep kendiri yang negatif boleh memberi kesan yang positif dalam proses pencegahan dan pemulihan ${ }^{65}$ khususnya dalam membina nilai kesedaran dan keinsafan. Daripada perspektif Islam, manusia digalakkan untuk selalu

\footnotetext{
${ }^{64}$ Ibn Qayyīm al-Jawziyyah, Madarīj al-Sālikīn Bayn İyyāk Na 'bud wa Iyyāk Nasta 'īn, jil. 1 (Beirut: Dār al-Kitāb al-'Arabī, t.t), 169.

65 Trice \& Roman, Social Problems, 538-546.
} 
melakukan muhasabah diri bagi mencari kesempurnaan dan kekurangan yang telah dilakukan. ${ }^{66}$ Melalui muhasabah diri manusia mampu untuk memperbaiki diri agar tidak bersarang di dalam hatinya sifat-sifat tercela. ${ }^{67}$

Selain daripada itu, berlaku perubahan yang lebih positif terhadap penilaian banduan wanita terhadap aspek penyelesaian tugasan dan bakat diri mereka setelah melalui Program Pembangunan Sahsiah (PPS). Pengkaji mendapati ini berkait dengan peluang banduan wanita menunjukkan perubahan diri mereka di dalam Program Kemahiran di Fasa 3. Di dalam program ini mereka diberi bimbingan melalui kemahiran menjahit, membuat produk bakeri dan sejuk beku, dan kemahiran melakukan spa dan kecantikan. Islam menuntut umatnya melakukan segala tugas dan tanggungjawab dengan sebaiknya. Tanggungjawab perlu ditunaikan dengan amanah dengan berusaha menepati segala ketetapan mengikut apa yang telah dipersetujui. Ini menunjukkan pengetahuan agama yang diperoleh banduan wanita melalui kelas pengajian semasa di Fasa 2 diimplementasikan sebaik yang boleh dalam melaksanakan tanggungjawab yang diberikan semasa di Fasa 3.

Selain dari itu, keputusan Hipotesis 2 iaitu hubungan positif nilai keagamaan dan konsep kendiri menunjukkan bahawa ilmu agama dapat membina konsep kendiri banduan wanita yang lebih baik terutama terhadap nilai moral dan penyelesaian tugasan. Skop nilai moral yang meliputi rasa setia, patuh, bersifat benar, mempunyai kualiti yang baik serta boleh dipercayai dan skop penyelesaian tugasan pula yang meliputi rasa rajin, produktif, mempunyai tabiat kerja yang baik dan keupayaan untuk mengurus dan menyelesaikan tugas

${ }^{66}$ Damanhuri, Akhlak: Perspektif Pemikiran Tasawuf Abdurrauf AsSingkili, 214.

${ }^{67}$ Hanafi Mohamed, Penyakit Rohani Dan Rawatannya Dalam Islam, 133. 
dengan berkesan merupakan tuntutan dan ajaran yang terkandung di dalam Islam. Islam menuntut manusia agar sentiasa melakukan kebaikan dan kebenaran serta melakukan tanggungjawab dengan penuh amanah dan kejujuran bagi mencapai kebahagiaan di dunia mahupun di akhirat. ${ }^{68}$

Di samping itu, nilai keagamaan dikenal pasti menyumbang kepada pembinaan konsep kendiri yang seimbang. Ini berdasarkan analisis yang menunjukkan hubungan negatif di antara konsep kendiri dari aspek kuasa dan nilai keagamaan $(\mathrm{r}=-.047, \mathrm{p}>0.05)$. Walaupun tidak mempunyai hubungan yang signifikan, dapatan ini secara tidak langsung menunjukkan nilai keagamaan sedikit sebanyak dapat mengurangkan rasa berkuasa, dominan dan kuat dalam diri banduan wanita. Islam melarang manusia daripada memiliki sifat ujub iaitu sifat bangga, kagum dan hairan terhadap diri sendiri kerana sifat tersebut boleh membawa kehancuran dalam hidup manusia. ${ }^{69}$ Terutama merasa kagum dan bangga dengan kehebatan diri sehingga timbul rasa berkuasa dan memiliki kekuatan. Ini kerana rasa berkuasa dan kuat akan mendorong manusia untuk memandang rendah kepada orang lain dan tidak takut dengan sesiapa atau apa-apa sehingga tidak merasa bersalah melanggar undang-undang dan menindas orang lain.

Hasil kajian mendapati, terdapat tiga aspek keagamaan yang perlu dititik beratkan dalam membangunkan konsep kendiri banduan wanita iaitu dengan (1) meningkatkan kefahaman banduan wanita terhadap ilmu agama terutama dengan memberi penekanan terhadap, (2) aspek akidah dan (3) ibadah/syariat. Berdasarkan al-Quran surah al-An`ām ayat

68 Muhammad Jamaluddin al-Qasimi ad-Dimasyqi, Mutiara Ihya' Ulumuddin Hak Milik Muslim: Imam al-Ghazali, terj. Norzuzilawati et al. (Shah Alam, Selangor: Illusion Network, 2009), 953.

${ }^{69}$ Al-Ghazālī, Ihyyā' 'Ulūm al-Dīn, 4:585. 
54, salah satu sebab seseorang melakukan dosa kerana kejahilan diri. Oleh itu, melalui pengajian agama yang mereka ikuti di dalam penjara dapat membantu mereka meningkatkan kefahaman agama dan membantu mereka menentukan sesuatu perbuatan itu benar atau salah (keluar dari kejahilan).

Penekanan aspek akidah pula merupakan tunjang kepada agama Islam. Menurut Yūsuf al-Qarāḍāwi kekuatan akidah yang berdasarkan kepercayaan kepada keesaan Allah SWT dan kewujudan hari akhirat dapat memerdekakan diri manusia dari kemahuan dan perbuatannya, sehingga menimbulkan rasa tanggungjawab dalam segala perbuatan tanpa melupakan kekuasaan Allah SWT yang mana manusia mesti tunduk terhadap segala perintahnya. $^{70}$ Oleh itu, dengan kekuatan akidah dapat meningkatkan keyakinan diri banduan wanita untuk melakukan segala tanggungjawab tanpa merasa terpaksa selagi perbuatan tersebut tidak menyalahi perintah Allah SWT.

Penekanan dalam melaksanakan tuntut ibadah dan syariat terutamanya dalam melakukan amalan-amalan wajib seperti solat dan puasa turut dapat membantu membina konsep kendiri banduan wanita yang positif. Melakukan ibadah dan syariat mempunyai kaitan dengan kekuatan akidah. Menurut Mohd. Radhi, melalui penghayatan terhadap ibadah yang telah disyariatkan dapat mengukuhkan akidah seseorang itu. ${ }^{71}$ Ini kerana melalui amalan ibadah yang dilakukan dapat mengukuhkan hubungan di antara manusia dengan Pencipta. Hasilnya, individu tidak mudah dipengaruhi dengan penilaian manusia dan lebih mengutamakan penilaian Allah SWT terhadap dirinya. Oleh itu, manusia bebas daripada dipengaruhi oleh penilaian atau pandangan

${ }^{70}$ Yusuf al-Qaradawi, Iman Dan Kehidupan, 29 \& 55. Berdasarkan alQuran, Surah al-Zalzalah (99):7-8.

${ }^{71}$ Mohd Radhi, Akidah Dan Pembangunan Tamadun, 73. 
manusia dan cukup membina diri mengikut acuan Islam yang berpandukan al-Quran dan Sunnah.

\section{Kesimpulan}

Kesimpulannya, usaha yang dilaksanakan oleh pihak JPM dengan menjadikan program keagamaan sebagai salah satu modul utama dalam program pemulihan merupakan usaha yang berkesan dalam membina psikologi banduan wanita. Modul keagamaan yang dilaksanakan memiliki ciri-ciri terapi tazkiyyah al-nafs yang disarankan di dalam Islam seperti menunaikan solat fardu di samping galakan dalam melakukan solat-solat sunat, berpuasa, dan mempelajari dan membaca al-Quran. Kesannya program agama yang dilaksanakan bukan sahaja membantu memberi nilai kesedaran dan keinsafan malah, mampu membina konsep kendiri banduan wanita yang lebih positif. Konsep kendiri positif amat perlu kerana ia menjadi asas dalam mencapai matlamat pemulihan tingkah laku banduan wanita sebelum mereka dibebaskan kelak.

\section{Rujukan}

Al-Dimasyqi, Muhammad Jamaluddin al-Qasimi. Mutiara Ihya' Ulumuddin Hak Milik Muslim: Imam al-Ghazali. terj. Norzuzilawati et al. Shah Alam, Selangor: Illusion Network, 2009.

Ahmad Hisham Azizan \& Che Zarrina Saari, "Terapi Solat dalam Menangani Penyakit Gelisah (Anxiety) menurut Perspektif Psikoterapi Islam," Jurnal Usuluddin 10 (2009): 1-43.

Azizi Yahaya, Fawziah Yahya, Zurihanmi Zakaria \& Noordin Yahaya. Pembangunan Kendiri. Johor: UTM, 2005.

Basri Ibrahim, Mohd Safri Al-Azhari \& Ahmad Tarmizi Taha. Pembersihan Jiwa menurut Al-Quran, al-Sunnah \& Amalan Salafus Soleh. Batu Caves: Al-Hidayah House of Publishers Sdn. Bhd, 2013. 
Bernburg, J. G. "Labeling Theory." In Handbook on Crime and Deviance. ed. Krohn, M. D., Lizotte, A. J. \& Hall, G. P. London: Springer, 2009.

Al-Bukhārī. Sahịh al-Bukhārī. ed. Muhammad 'Abd alQādir Aḥmad 'Ațā', Jil. 1 \& 3. Kaherah: Dār al-Taqwā li al-Turāth, 2001.

Che Zarrina Sa'ari, "Penyakit Gelisah (Anxiety / al-Halū') dalam Masyarakat Islam dan Penyelesaiannya menurut Psiko-Spiritual Islam," Jurnal Usuluddin 14 (2001): 122.

Damanhuri. Akhlak: Perspektif Pemikiran Tasawuf Abdurrauf As-Singkili. Banda Aceh: ArRijal Publisher, 2011.

Fariza Md. Sham, Salasiah Hanin Hamjah \& Mohd. Jurairi Sharifudin. Personaliti dari Perspektif alGhazali. Bangi: Universiti Kebangsaan Malaysia, UKM, 2008.

Fitts, W.H. \& Warren, W.L. Tennessee Self-Concept Scale (TSCS:2) Manual $2^{\mathrm{t}} \mathrm{h}$ ed. Los Angeles CA: Western Psychological Services, 1996.

Garis Panduan Kurikulum Pengajian dan Bimbingan Islam serta Aktiviti Harian Halaqah Institusi Penjara Malaysia, Unit Agama Bahagian Pemulihan dan Rawatan Jabatan penjara Malaysia, tidak diterbitkan, 124.

Al-Ghazālì, Abū Hāāmid Muhammad. "Khulāṣah alTașānif fí al-Tașawwuf.” Dalam Majmū 'ah Rasā'il alImām al-Ghazālì. Beirut: Dār al-Minhajil, 1994.

Al-Ghazālī, Abū Ḥāmid Muhammad. Ihyā' 'Ulūm al-Dìn. taḥ̂īq As`ad al-Șāgharji, jil. 3 \& 4. Damsyiq: Dār alFayhā', 2010.

Gold, M., \& Mann, D.W. "Delinquency as a Defense." American Journal of Orthopschitry 42 (1972): 463-479.

H. Imam Malik. Psikologi Umum Sebuah Pengantar. Surabaya: Lembaga Kajian Agama dan Filsafat (eLKAF), 2005. 
Habibah Elias \& Noran Fauziah Yaakub. Psikologi Personaliti. Kuala Lumpur: Dewan Bahasa dan Pustaka, 2006.

Hanafi Mohamed. Penyakit Rohani dan Rawatannya dalam Islam. Kuala Lumpur: Pustaka Haji Abdul Majid, 1998.

Haron Din. Islam: Ibadah Pembina Tamadun Manusia. Kuala Lumpur: PTS Millennia, 2007.

Hermann, D.S., McWhirter, J.J. \& Sipsas-Hermann, A., "The Relationship Between Dimensional Self Concept and Juvenile Gang Involvement: Implications for Prevention, Intervantion, and Court Referred Diversion Programs," Behavioral Sciences and the Law 15 (1997): 181-194.

Ibn Qayyīm al-Jawziyyah. Madārij al-Sālikīn Bayn Iyyāk Na bud wa Iyyāk Nasta īn, Jil. 1. Beirut: Dār al-Kitāb al-'Arabī, t.t.

Ibn Qayyīm al-Jawziyyah. Tuhfah al-Mawdūd bi Ahkām al-Mawlūd, tahqiq 'Abd al-Qādir al-Arna'ūṭ. Damsyiq: Maktabah Dār al-Bayān, 1971.

Kamus Dewan. ed. ke-4. Kuala Lumpur: Dewan Bahasa \& Pustaka, 2005.

Kholil Lur Rochman, "Terapi Penyakit Hati menurut Ibn Taimiyah dalam Perspektif Bimbingan Konseling Islam," Jurnal Dakwah dan Komunikasi: Komunika 3(2) (Julai- Dis 2009): 196-221.

Laporan Tahunan Jabatan Penjara Malaysia 2002 \& 2005. McMurran et al., "Measuring Motivation to Change in Offenders," Psychology, Crime and Law 4 (1998): 4350.

Mohammad Salleh. Terapi Solat Tahajud. Kuala Lumpur: PTS Millennia Sdn. Bhd. 2008.

Mohd Radhi Ibrahim. Akidah dan Pembangunan Tamadun. Bandar Baru Nilai: Kolej Universiti Islam Malaysia, 2006. 
Mohd Salleh Lebar. Asas Psikologi Perkembangan. Kuala Lumpur: Utusan Publication \& Distributors Sdn. Bhd, 1994.

Mostafa Kamal Mokhta, "Konsep Pembangunan Rohani Manusia: Kajian Perbandingan di antara Sufisme dan Psikologi," Jurnal Psikologi Malaysia 15 (2001): 1-20.

Najātī, Muhammad 'Uthmān. Al-Hadīth al-Nabawī wa 'Ilu al-Nafs. Kaherah: Dār al-Shurūq, 1988.

Program Halaqah: Di Institusi Penjara. Dokumentasi Jabatan Penjara Malaysia, tidak diterbitkan.

Al-Qaradawi, Yusuf. Iman dan Kehidupan, terj. Fachruddin HS. Shah Alam: Dewan Pustaka Fajar, 2005.

Rogers, C. R. Client-centered Therapy: Its Current Practice, Implications and Theory. New York: Houghton Mifflin, 1951.

Roseberg, F. R., Rosenberg. M. \& McCord. J, "SelfEsteem and Delinquency," Journal of Youth and Adolescence 7(3) (1978): 279-294.

Al-Shāmī, Șālih Aḥmad, al-Muhadhdhab min Ihyā' Ulūm al-Dìn, jil. 2. Damsyiq: Dār al-Qalam, 2010.

Shavelson, R.J. \& Bolus, R., "Self-concept: The Interplay of Theory and Method," Journal of Educational Psychology 74 (1982): 3-17.

Trice, \& Roman, P., "Delabeling, Relabeling, and Alcoholics Anonymous," Social Problems 17 (1970): 538-546. 